\title{
The Impact of the Legendary Love between Yeats and Maud Gonne on Yeats's Creation of Love Poems
}

\author{
Yue Zhang \\ College of Foreign Languages, North China Institute of Science and Technology, Langfang, China \\ Lijun Wang \\ College of Foreign Languages, North China Institute of Science and Technology, Langfang, China
}

\begin{abstract}
W. B. Yeats (1865-1939) is an Irish poet, dramatist and prose writer. T. S. Eliot considers him as the greatest English poet in the twentieth century. The classic and legendary love between Yeats and Maud Gonne is greatly well-known in the Western World and permeates from generation to generation. This essay gives a brief introduction to this romantic and sorrowful legend of love and attempt to analyze its impact on Yeats's creation of love poems in different period of life.
\end{abstract}

Index Terms-Yeats, Maud Gonne, love poems

\section{INTRODUCTION}

William Butler Yeats is a world-known Irish poet and playwright. After winning the Nobel Prize in Literature in1923, T. S. Eliot honored Yeats as "the greatest poet of our age-certainly the greatest in this language" (Stead, 1986, p.45). In a Yeats memorial lecture in 1940, T. S. Eliot regarded Yeats as "one of those few whose history is the history of their own time, who are a part of the consciousness of an age which cannot be understood without them" (Heaney, 2004, p.1). The Royal Swedish Academy thinks highly of him "for his always inspired poetry, which in a highly artistic form gives expression to the spirit of a whole nation" (Cheng, 2010, p.1). Modern readers view Yeats as the greatest modern poet in English language even more than Eliot.

Yeats lives a legendary life, as his life is woven with the times and his country. He combines his fate with the fate of Ireland, his literary creation with the revival of Irish literature, and his personal life with his artistic creation. Born in June, 1864, he was raised in a Dublin painter's family. His father was John Butler Yeats, who was a lawyer and then turned to an Irish painter. Yeats's mother came from a wealthy family - the Pollexfens. The family had a prosperous milling and shipping business. Yeats spent his early years in London and Sligo, a beautiful county on the west coast of Ireland, where his mother had grown. Sligo later appeared many times in some of his poems. Once, Yeats said that "the place that has really influenced my life the most is Sligo" (Ellmann, 1987, p.25). In 1881, the whole family returned to Dublin, the capital city of Irland. At the beginning, Yeats was willing to become a painter as his father and entered the arts school to pursue his study in Dublin. However, his gifts in poetry drove him to quit painting two years later and began specializing in poems writing. Once began, his fascination grew out of control and unmanageable and he consequently became an outstanding poet in Irish as well as the world. In 1923, Yeats was awarded the Nobel Prize in Literature. People said his poems were always inspirational poetry, and his fine art form expressed the spirit of the whole nation and his efforts of melting Celtic nation and English nation together has never been implemented in the political field before, but it has become a reality in the fantasy world of poetry.

Without any doubt, Yeats is one of the greatest poets in the twentieth century worth of researching and evaluating. Firstly, Yeats is a dominant and influential figure for his contribution to the revival of Irish literature and the Ireland's independence. Secondly, Yeats is a poet who can feel the pulse of the times. Thirdly, Yeats's poems truthfully record his inner world and the world around him. He tries to create a coherent poetic world to put everything in order. At the same time, his poems record the history in his times. Many a immortal masterpieces are passed down through the generations, which consist of his reflections on the temporary time and the poet's legendary life experience. His poetry is a blend of romantic and realistic factors, including the realistic description of the Irish liberation movement, e.g. "Easter 1916", "Sailing to Byzantium" and "Byzantium", etc. These works reflect the poet's philosophy of valuing the contradictory unity between life and death, good and evil, beauty and ugliness. Yeats admits, "We are what we are because almost without exception we have had some part in public life in a country where public life is simple and exciting" (Yeats, ed. 1936, p.xv-xvi). However most of his poems are love poems that are rich in romantic colors. A much-told tale is that Yeats's numerous classic love poems are almost all written for one. People are struck by the poet love of constancy and may get a better understanding of Yeats's love poems from his love story. 
The girl to whom Yeats presented his whole life was called Maud Gonne, a beautiful actress and daughter of a British colonel In Ireland. When 23 years old Yeats met her on January 30, 1889, she was only 22. Not only had Maud Gonne got outstanding beauty and slender figure, but she showed great sympathy to the Irish people after she witnessed the miserable condition of the Irish people under the oppression of Britain. She gave up the upper class life of Duplin without hesitation and devoted herself into the campaign of fighting for the independence of Irish people. Eventually she became one of the leaders. To some extent, Maud Gonne could be considered as the real Scarlett in Gone with the Wind. What she had got was not only the beautiful appearance but also a brave and life loving heart. A kind of extraordinary beauty surrounded her. In the eyes of the poet Yeats, Maud Gonne was the goddess in heaven, pretty but unreachable which put a special and mysterious ring around her beauty.

"I thought of your beauty, and this arrow; Made out of a wild thought, is in my marrow; There's no man may look upon her, no man; As when newly grown to be a woman, Tall and noble; but with face and bosom Delicate in color as apple blossom; This beauty's kinder, yet for a reason; I could weep that the old is out of season" (Finneran, 1996, p.77). Yeats described his first meeting with her as this, which is taken from one of his love poem "The Arrow". He fell in love with Maud at first sight and was passionately devoted to this love. However, Maud Gonne always kept him at an arm's length. In July, 1891, Yeats misunderstood one of her letters and thought that she gave him the sign of love. He ran to propose to her right away. But she refused and said, "Poets should never marry. The world should thank me for not marrying you" (Kelly and Donville, 1986, p.54). From then on, she rejected another three proposes of him. Maud Gonne married the Irish commander Lieutenant McBride. Their marriage was full of ups and downs but she was quiet stubborn. Even when their marriage failed, she still refused Yeats's love. Despite this, Yeats's love for Maud Gonne was life-long, and endless pain continues throughout his life.

The hopeless pain and misfortune drove Yeats to write many love poems. During decades of time, from various angles, this love for Maud Gonne inspired Yeats. His love poems sometimes depicted passionate love, sometimes desperate hatred, but most of them showed the complicated psychological entanglement between love and hatred.

"When You are Old", "The White Birds", "He Wishes for the Clothes of Heaven", "Never Give all the Heart" and "No Second Troy" are all the famous works of Yeats.

\section{YeATS’s Love PoEMS IN DifFERENT STYLES}

Due to the difference of age and time, Yeats's love poems written for Maud Gonne own different styles, which could be roughly divided into the following three:

\section{A. Passionate Love Poems of Young Age}

Yeats met Maud at a quite young age when he was full of passion, enthusiasm and confidence for love. In spite of his frequent failures, the poet was faithful to his love and pursued his love courageously. During this period, Yeats's love poems are mostly permeated with the yearning and pursuit of sweet love, his deep affection for his lover Maud Gonne, like "He Wishes for the Clothes of Heaven" and "The White Birds".

\section{HE WISHES FOR THE CLOTHES OF HEAVEN}

HAD I the heavens' embroidered cloths

Enwrought with golden and silver light,

The blue and the dim and the dark cloths

Of night and light and the half-light,

I would spread the cloths under your feet:

But I, being poor, have only my dreams;

I have spread my dreams under your feet;

Tread softly because you tread on my dreams. (Finneran, 1996, p.73)

The first part of the poem demonstrates readers the poet's longing for love and beautiful life. In order to win the heart of his lover, the poet would like to "spread the cloths under your feet", from which the readers can sense the poet's determination to sacrifice everything for his lover. In the later part, the poet seems as if he returned from the beautiful aspiration to the earth. And on the earth, the poet is down and out. But he is not discouraged because of hope. This poem is full of the energetic youth from the beginning to the end. Young Yeats was not afraid of any challenge and failure and he is willing to pay everything for his beloved in order to win her heart. Between the lines the poet's desperate courage and momentum for love are vividly conveyed.

In addition, another well-known love poem "The White Birds" shares different approach but equally satisfactory result.

\section{THE WHITE BIRDS}

Would that we were, my beloved, white birds on the foam of the sea!

We tire of the flame of the meteor, before it can fade and flee;

And the flame of the blue star of twilight, hung low on the rim of the sky,

Has awakened in our hearts, my beloved, a sadness that may not die.

A weariness comes from those dreamers, dew-dabbled, the lily and rose;

$\mathrm{Ah}$, dream not of them, my beloved, the flame of the meteor that goes, 
Or the flame of the blue star that lingers hung low in the fall of the dew:

For I would we were changed to white birds on the wandering foam: I and you!

I am haunted by numberless islands, and many a Danaan shore,

Where Time would surely forget us, and Sorrow come near us no more;

Soon far from the rose and the lily, and fret of the flames would we be,

Were we only white birds, my beloved, buoyed out on the foam of the sea! (Finneran, 1996, p.41)

There is a story about this poem. Yeats and Maud Gonne walked together on the cliffs at Howth the day after Yeats's first proposal and the first of Maud's many rejections. Two seagulls flew overhead, provoking Maud's comment that of all birds, she would choose the shape of a seagull. Three days later Yeats sent her the poem "The White Birds", characteristically altering her singular wish to a more consolatory plural fantasy. Readers can sense the endless sweetness of youth from the page. The poet expresses his love straightforwardly without any hesitation. His love is pure and romantic, but with kind of profoundness. People can not see sophisticated worry and wretched timidity, but only a flaming heart of the poet.

\section{B. Mature Love Poems of Middle Age}

With the growing of age and experience of the poet, his attitude toward love and life is becoming mature gradually. During this period, there is less wild teenage love, but more understanding of life and hopelessness of unreachable love. The representative works of this period are the famous "No Second Troy" and "Never Give all the Heart".

NO SECOND TROY

Why should I blame her that she filled my days

With misery, or that she would of late

Have taught to ignorant men most violent ways,

Or hurled the little streets against the great,

Had they but courage equal to desire?

What could have made her peaceful with a mind

That nobleness made simple as a fire,

With beauty like a tightened bow, a kind

That is not natural in an age like this,

Being high and solitary and most stern?

Why, what could she have done, being what she is?

Was there another Troy for her to burn? (Finneran, 1996, p.91)

This poem not only contains the poet's negative attitude of love after he is repeatedly suffered setbacks, but reflects the characteristics of that time. Yeats's age coincided with the era of the vigorous Irish liberation movement. Maud Gonne was a radical nationalist who advocated winning the independence through violent revolution. However, her ideas were contradictory with Yeats's revolutionary ideas. Yeats sustained the Irish liberation movement, but he opposed violent revolution. He considered the sacrifice of common people in revolution was unnecessary and kind of foolish. He pinned his hope on British government and believed that they could win the Irish independence and people's liberty by the improvement policies of government. Due to the radically different views of revolution, it was doomed that Yeats and Maud Gonne could not be together. Although Maud Gonne was captivated by Yeats's talents and moved by his burning passion of love, the love would finally become a victim of history and the era which was overwhelmed in the vast wave of history. People felt endless regret for Yeats, but perhaps just thanks to the love setbacks, they had brought more and more insightful life feeling for Yeats, thus inspired more profound creative enthusiasm in his poems.

NEVER GIVE ALL THE HEART

Never give all the heart, for love

Will hardly seem worth thinking of

To passionate women if it seem

Certain, and they never dream

That it fades out from kiss to kiss;

For everything that's lovely is

But a brief, dreamy, kind delight.

O never give the heart outright,

For they, for all smooth lips can say,

Have given their hearts up to the play.

And who could play it well enough

If deaf and dumb and blind with love?

He that made this knows all the cost,

For he gave all his heart and lost. (Finneran, 1996, p.79)

This poem vividly reflects Yeats's true feelings after suffering frustrations in love. The poem is mixed with a little resentment of his lover, disappointment of his love and the fundamental change of his ideas of love. The reader can feel the dispirited and discouraged of the poet between the lines, the infinite grief after passion. 


\section{Peaceful and Profound Love Poems of Old Age}

When the passionate moments and frustrations are all gone, the poet returns to clam after experiencing both pleasure and agony. Yeats of the old age seems of have seen through the vanity of life. His poems of this period become peaceful and profound, like a cup of good old brandy leaving readers endless aftertaste.

THE WILD SWANS AT COOLE

The trees are in their autumn beauty,

The woodland paths are dry,

Under the October twilight the water

Mirror a still sky;

Upon the brimming water among the stones

Are nine-and-fifty swans.

The nineteenth autumn has come upon me

Since I first made my count;

I saw, before I had well finished,

All suddenly mount

And scatter wheeling in great broken rings

Upon their clamorous wings.

I have looked upon those brilliant creatures,

And now my heart is sore.

All's changed since I, hearing at twilight,

The first time on this shore,

The bell-beat of their wings above my head,

Trod with a lighter tread.

Unwearied still, lover by lover,

They paddle in the cold

Companionable streams or climb the air;

Their hearts have not grown old;

Passion or conquest, wander where they will,

Attend upon them still.

But now they drift on the still water,

Mysterious, beautiful;

Among what rushes will they build,

By what lake's edge or pool

Delight men's eyes when I awake some day

To find they have flown away? (Finneran, 1996, p.131)

This poem was written in 1919, when Yeats went on a vacation in Coole. Coole was a rural mansion owned by Mrs. Gregory. For many years, Yeats had been going for summer vacation. Mrs. Gregory was the widower of a proconsul. And she passionately advocated the Irish Renaissance. This poem is inspired by the swans in Coole. For 19 years, Yeats had been seeing the swans frolicking in the water and flying in the sky. This poem shows readers both the happy and sorrowful sides of life: a sigh of the bygone days on the one hand, a praise for the vibrant youth on the other hand. Through the ages, a beautiful swan is refined posture and serene dignified manner by the favor of people and has become the symbol of nobility and purity. The poet would like to depict his mood and understanding of love and life by way of describing the swans.

\section{THE MAN AND THE ECHO}

Man

In a cleft that's christened Alt

Under broken stone I halt

At the bottom of a pit

That broad noon has never lit,

And shout a secret to the stone.

All that I have said and done,

Now that I am old and ill,

Turns into a question till

I lie awake night after night

And never get the answers right.

Did that play of mine send out

Certain men the English shot?

Did words of mine put too great strain

On that woman's reeling brain?

Could my spoken words have checked 
That whereby a house lay wrecked?

And all seems evil until I

Sleepless would lie down and die

Echo

Lie down and die.

Man

That were to shirk

The spiritual intellect's great work,

And shirk it in vain. There is no release

In a bodkin or disease,

Nor can there be work so great

As that which cleans man's dirty slate.

While man can still his body keep

Wine or love drug him to sleep,

Waking he thanks the Lord that he

Has body and its stupidity,

But body gone he sleeps no more,

And till his intellect grows sure

That all's arranged in one clear view, pursues the thoughts that I pursue,

Then stands in judgment on his soul,

And, all work done, dismisses all

Out of intellect and sight

And sinks at last into the night.

Echo

Into the night.

Man

O Rocky Voice,

Shall we in that great night rejoice?

What do we know but that we face

One another in this place?

But hush, for I have lost the theme,

Its joy or night-seem but a dream;

Up there some hawk or owl has struck,

Dropping out of sky or rock,

A stricken rabbit is crying out,

And its cry distracts my thought. (Finneran, 1996, p.345)

The Man and the Echo is a poem written in Yeats's old age and perhaps is little known among Yeats's countless lyrics. But this poem inherits Yeats strong lyric style, and combines the deep feeling of life at the same time. This poem alternates the voice of man with echo. This arrangement is obviously generated from Greek mythology, Goddess Echo's legend. And what the echo communicates is the man's own most extreme and exhausted recognitions. The echo marks the limits of the mind's operations even as it calls the mind forth to its utmost exertions. Just like Heaney said, "I rhyme to see myself, to set the darkness echoing."

WHAT WAS LOST

I sing what was lost and dread what was won,

I walk in a battle fought over again,

My king a lost king, and lost soldiers my men;

Feet to rising and setting may run,

They always beat on the same small stone. (Finneran, 1996, p.312)

For Yeats, Maud Gonne is both "what was lost" and "what was won". Because the lifelong bitter love is the miserable "what was lost", while the immortal and widespread poems compose "what was won". The irreconcilable contradiction between "what was lost" and "what was won", the emotional opposition between "sing" and "dread" form the philosophic thought of this poem. On the one hand, Yeats in realistic world can achieve "what was won" virtually in his ideal kingdom as a result of "what was lost" in his longing for love through his whole life; on the other hand, the poet feels dreadful and worry about accomplishing "what was won" in the real world, because to this extent, "what was won" makes another kind of "what was lost". And "what was lost" here means exhaustion of vigor of life and creative power. Therefore, the poet can only involve himself in the seesaw battle of "what was lost" and "what was won".

\section{CONCLUSION}


As one of the greatest English-language poets of the $20^{\text {th }}$ century, Yeats experiences the transition from Romanticism to Modernism, and his poetic styles also change with time. His poetry, including his love poetry, is generally divided into three periods. Through the analysis in Yeats's love poetry, it is found that the attitude of Yeats toward love is evolving all the time. In the early period, Yeats thinks that love should be nature, and it occurs and wanes naturally. And he thinks that love is more spiritual than sexual (Gan, 2010). His love poems in this period are full of passion and enthusiasm. Therefore, when Yeats describes his pursuing of love, his love poems are full of passion and enthusiasm. In the middle period, Yeats expresses his longing for the immortal love. However, as he and his beloved grow old, he realizes that their love could not be immortal as their lives are perishable. In the late period, Yeats expresses his opinion that love is the unity of body and soul. His understanding of love reaches to a peaceful and profound realm.

Yeats's love for Maud Gonne lasts for a lifetime, which exerts a significant impact on the poet. This love is not only reflected in Yeats's love poems, but his works of other types. For instance, in his poem "Easter 1916" which depicts the Irish Easter rebellion in 1916, the poet describes mainly several heroes, one of which is the husband of Maud Gonne John·McBride. Despite his grudge, the poet still gives an objective appraisal toward him regardless of personal grievances, which shows the greatness of the poet.

All in all, poets need inspiration. Poets need passion. The great poet even needs these. Only the true reflections of life and personal experiences can inspire poets' creation enthusiasm to write the most excellent works. The love between Yeats and Maud Gonne is recounted by people from generation to generation, not because of its perfection but its poignant sadness leaving us everlasting regret. But this sad love is also the resource of countless great love poems. This classic love gives Yeats profound feeling for life and also brings forth the lines after lines of immortal words in front of us.

\section{REFERENCES}

[1] Cheng, Haixia. (2010). On W. B. Yeats's Spiritual Ambivalence in his Early Poems. Shanghai: Shanghai Jiaotong University, 1.

[2] Ellmann, Richard. (1987). Yeats: The Man and The Masks. Harmondsworth: Penguin Books, 25.

[3] Finneran, Richard J. (1996). The Collected Works of W.B. Yeats Volume I: The Poems: Revised Second Edition. Ed. New York: Scribner, 41-345.

[4] Gan, Wenting. (2010). A Study of Images in W. B. Yeats's Love Poetry. Guangzhou: South China University of Technology, 69.

[5] Heaney, Seamus. (2004). W. B. Yeats: Poems, London: Faber, 1.

[6] Kelly, John and Donville, Eric. (1986).The Collected Letters of W. B. Yeats, Vol. I, eds., Oxford: Clarendon Press, 54.

[7] Stead, Christian Karlson. (1986). Pound, Yeats, Eliot and the modernist movement. London: Macmillan, 45.

[8] Yeats, W. B., ed. (1936).The Oxford Book of Modern Verse, 1892-1935. London: OUP, xv-xvi.

Yue Zhang, Assistant Professor in North China Institute of Science and Technology, has received a M. A. Degree from North China Electric Power University, China, 2007. Currently she works at the College of Foreign Languages in NCIST and has been teaching college English for more than 7 years. Her research interests include college English teaching, British and American Literature, the philosophy of translation, and Sino-English translation practice. She has published more than 10 research papers on college English teaching, British and American Literature studies.

Lijun Wang, lecturer in North China Institute of Science and Technology, has received a M. A. Degree from Shandong University, China, 2008. Currently she works at College of Foreign Languages in NCIST and has been teaching college English for more than 6 years. Her research interests include college English teaching, linguistics, British and American Literature, and Sino-English translation practice. She has published 8 research papers on college English teaching, British and American Literature studies. 